\title{
Segmentasi Citra Warna Otomatis Rambu Lalu Lintas dengan Penerapan Mask Thresholder
}

\author{
Khoerul Anwar" ${ }^{\# 1}$, Mahmud Yunus ${ }^{\# 2}$, Sujito ${ }^{\# 3}$

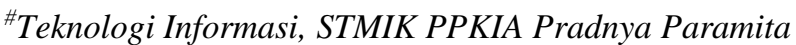 \\ Jl. LA. Sucpto 249 A Malang \\ 1alqhoirestimata.ac.id \\ ${ }^{2}$ yoenoes@gmail.com \\ ${ }^{3}$ sujito@stimata.ac.id
}

\begin{abstract}
Abstrak-Segmentasi rambu jalan dan sistem pengenalan merupakan aspek penting dan esensial untuk digunakan pada sistem autopilot, smart car atau autonomous vehicle yang memungkinkan kendaraan dapat berjalan tanpa pengemudi manusia. Namun demikian pada paper ini citra rambu jalan yang diproses dalam bentuk image dan bukan vidio/kamera. Penelitian ini bertujuan memperoleh citra warna rambu jalan dengan presisi yang tinggi. Pada penelitian ini ditawarkan metode segmentation rambu jalan dengan mengembangkan Fuzzy C-means dengan menginjeksikan teknik masktresholder untuk mendapatkan hasil segmentasi warna rambu jalan dengan presisi tinggi. Mula-mula citra dideteksi dalam ruang warna RGB kemudian diubah menjadi model warna L*a*b dan dilanjukan ekstraksi untuk mendapatkan komponan warna *a*. Fuzzy $C$-means dterapkan pada citra warna *a* untuk segmentasi foreground dan background. Proses dilanjutkan dengan operasi opening - closing dan hole filling untuk mereduksi noise pada hasil segmentasi. Sampai pada tahap ini hasil segmentasi yang diperoleh adalah citra binary dimana foreground dalam warna putih dan bacground dalam warna hitam. Oleh karena itu untuk mendapatkan citra hasil segmentasi rambu jalan dalam ruang warna RGB maka diperlukan proses konvolusi. Teknik konvolusi yang dilakukan pada penelitian ini adalah dengan mengalikan tiap piksel citra mask tresholder dengan citra semula dalam ruang warna RGB. Citra mask tresholder yang digunakan dalam penelitian ini adalah citra binary hasil segmentasi dengan Fuzzy Cmeans. Metode yang ditawarkan telah diuji dengan citra rambu jalan sejumlah 18 citra. Hasil yang diperoleh menunjukkan kinerja metode yang diusulkan mampu mensegmentasi citra rambu jalan dalam sesuai warna citra semula. Menggunakan metode jaccard untuk mengukur akurasi kinerja didapat tingkat akurasi adalah $97,73 \%$.
\end{abstract}

Kata kunci - Rambu Jalan, Segmentasi, Fuzzy C-Means, Mask Thresholder, Konvolusi

\section{Pendahuluan}

Segmentasi rambu jalan dan sistem pengenalan merupakan aspek penting dan esensial dari "Sistem Dukungan Pengemudi (DSS)", karena rambu jalan mengarahkan pengemudi untuk mengemudikan kendaraan mereka dengan aman dan menentukan cara, kecepatan, dan belokan[1]. Saat ini mulai banyak penelitian-penelitian tentang autopilot, smart car atau autonomous vehicle yang memungkinkan kendaraan dapat berjalan tanpa pengemudi manusia. Salah satu modul penting yang harus dimiliki pada autonomous vehicle adalah pengenalan rambu-rambu lalu lintas secara otomatis[2]. Pengenalan rambu-rambu lalulintas secara otamatis dalam bidang computer vision adalah pekerjaan yang cukup rumit. Hal terpenting adalah bagaimana sistem mampu melokalisir tanda yang terpasang dapat dikenali dan diterjemahkan dengan benar oleh sistem. Sementara resistensi sistem secara real time adalah kecepatan kendaraan, lokasi dan warna rambu lalulintas. Citra tanda rambu lalulintas terpasang secara umum memiliki latar belakang yang komplek dan beragam. Oleh karena itu diperlukan teknik segmentasi objek untuk dapat mengenali tanda lalulintas.

Segmentasi citra sampai saat ini masih menjadi perhatian yang cukup penting dalam hal pengolahan citra digital. Segmentasi merujuk pada partisi [3][4] sebuah citra menjadi beberapa bagian yang didasarkan kemiripan ciri [5] atau keseragaman yang dimiliki [6]. Kegunaannya cukup penting khususnya terkait analisis dan aplikasi pengolahan citra digital. Tantangan yang dihadapi adalah tidak ada sebuah metode segmentasi yang mampu digunakan untuk semua kasus. Hal ini disebabkan citra memiliki perbedaan dalam bentuk warna, teksture, tingkat iluminasi dan noise yang berbeda.

Sistem pengenalan pada rambu lalu lintas memiliki dua fase utama, yaitu fase deteksi dan pengenalan rambu. Fase deteksi adalah fase untuk menyeleksi objek pada sebuah gambar dengan tujuan menemukan rambu itu sendiri. Melalui proses segmentasi maka hasil dari fase ini adalah Region of Interest (ROI) atau objek rambu tersebut. Hasil tersebut akan menjadi masukan untuk tahap pengenalan rambu (recognition). Fase ini merupakan fase untuk mendefinisikan arti dan tujuan dari rambu tersebut menggunakan template yang telah dipersiapkan atau metode lainnya[7]. Kecepatan pengenalan menjadi urgent ketika diterapkan untuk autonomous vehicle sistem. 
Segmentasi adalah proses yang kompleks dan menantang, terutama jika diterapkan pada gambar dengan latar belakang alami. Proses ini bertujuan untuk mengklasifikasikan luas area rambu lalulintas dan latarbelakangnya. Ada banyak literatur sebelumnya tentang segmentasi yang dikembangkan untuk citra dengan latarbelakang yang kompleks seperti oil palm [8], blueberry fruit [9], apple Harvesting [10], the Fruit-trees in Multi-stage Outdoors Orchard under Natural Conditions[11]. Berbagai penelitian tersebut menjadi sumber referensi.

Berdasar telaah literatur yang penulis lakukan sampai saat ini tidak ada yang membahas tentang teknik mendapatkan hasil segmentasi dalam bentuk citra warna. Demikian juga pada beberapa penelitian citra yang digunakan untuk konvolusi lazim menggunakan ukuran tertentu misal 3 × 3 dengan komponen piksel tertentu dengan nilai 0 sebagai pusat kernel.

Penelitian ini menawarkan kebaruan yaitu model kernel atau oleh penulis disebut mask thresholder dengan ukuran yang tidak lazim yaitu berukuran sama dengan citra asli/semula. Sementara teknik konvolusinya adalah perkalian piksel citra semula dan citta mask tresholder. Perkalian antar piksel pada indek piksel yang sama dari masing-masing matrik citra mask dan citra semula. Penjelasan detail dibahas pada dibagian metode penelitian.

Tujuan dari penelitian ini adalah memisahkan foreground dan background citra yang terdapat rambu jalan dengan menghasilkan citra rambu jalan dalam bentuk citra warna.

\section{MEtode PENELITIAN}

Metode yang diusulkan untuk melakukan segmentasi secara otomatis terhadap citra Rambu Lalulintas dengan latar belakang yang komplek dibagi dalam tiga tahapan: (1) Lokalisasi rambu lalulintas, (2) Tahapan persiapan pengolahan data (pre processing) dan (3) Segmentasi. Masing masing tahapan memiliki beberapa proses, gambar 1 menunjukkan detail tahapan proses untuk mendapatkan hasil segmentasi.

\section{A. Lokalisasi Rambu Lalulintas}

Lokalisasi rambu lalulintas dilakukan pada citra khususnya yang mempunyai background komplek. Proses ini untuk mengurangi area citra terhadap background. Hal yang dilakukan adalah dengan melakukan cropping citra. Contoh proses ini ditunjukkan oleh Gambar 2. (b) dan (d)

\section{B. Pra Proses}

Proses ini bertujuan untuk mendapatkan bagian citra dengan fokus area mendekati citra rambu lalulintas. Bagian ini dinamakan dengan region of interes (ROI) citra. ROI mempunyai berbagai ukuran seperti ditunjukkan pada Gambar 2 (Gambar 2(a) dan (c) citra dengan ukuran asal, Gambar 2(b) dan (d) hasil resize). Ukuran citra tersebut lebih kecil dari citra aslinya dengan mengurangi selain area rambu lalulintas. Resize terhadap citra asli dengan berbagai resolusi menjadi 200 x 200 piksel. Ukuran ini diharapkan untuk efisiensi waktu [12] proses seleksi ROI.
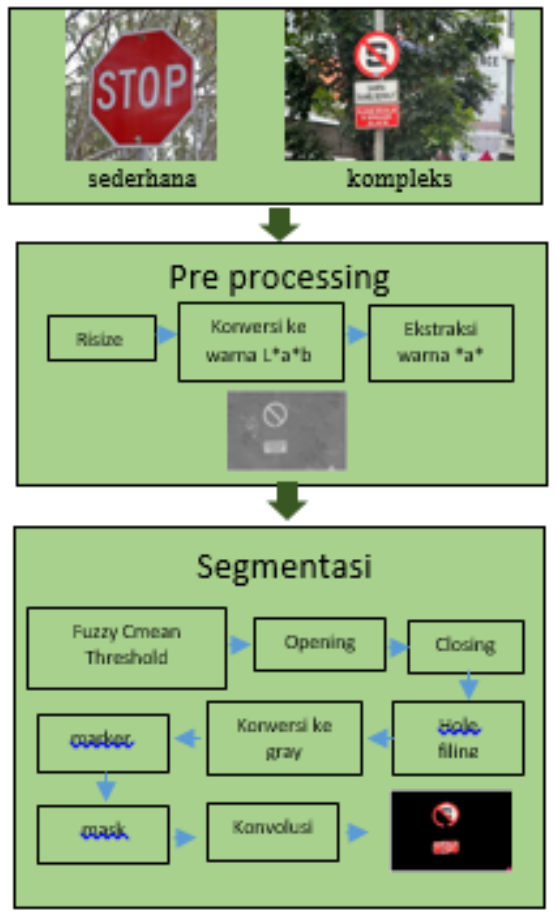

Gambar. 1 Diagram alur sistem

Komposisi warna citra asal adalah RGB dan untuk optimalisasi proses maka dikonversi ke citra $\mathrm{L}^{*} \mathrm{a} * \mathrm{~b}$. Dari warna $\mathrm{L}^{*} \mathrm{a} * \mathrm{~b}$ dipilih komponen $* \mathrm{a} *$ atau $\mathrm{b}$ untuk memperoleh rambu lalulintas yang potensial dari latar belakang yang komplek [13][14]. Konversi warna RGB ke L*a*b menggunakan formula[8] seperti tertulis di Persamaan (1)

$$
\begin{gathered}
\mathrm{L}=0.2126 \mathrm{R}+0.7152 \mathrm{G}+0.9722 \mathrm{~B} \\
\mathrm{a}=1.4749(0.2213 \mathrm{R}-0.339 \mathrm{G}+0.1177 \mathrm{~B})+128 \\
\mathrm{~b}=0.6245(0.1949 \mathrm{R}+0.6057 \mathrm{G}-0.8006 \mathrm{~B})+128
\end{gathered}
$$

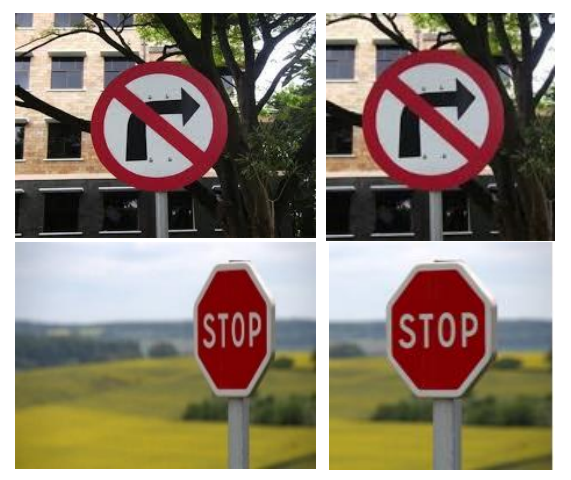

Gambar 2. Resize resolusi, (a)(c) citra dengan ukuran asal, (b)(d) hasil resize

Pada tahapan ini juga dilakukan proses perbaikan citra hasil konversi khususnya citra dengan komponen warna a atau b. dengan menerapkan Filter Gausian. Gaussian filtering adalah proses untuk mereduksi gangguan pada citra agar diperoleh citra dengan kualitas yang siap untuk 
diproses. Tahapan ini merupakan proses peningkatan domain spasial pada citra. Peningkatan domain spasial didasarkan pada piksel dalam rentang kecil (tetangga). Ini berarti intensitas transformasi ditentukan oleh nilai abu-abu dari titik-titik tersebut di dalam lingkungan, dan dengan demikian peningkatan domain spasial juga disebut operasi lingkungan atau pemrosesan lingkungan. Sebuah citra digital dapat dilihat sebagai fungsi dua dimensi $\mathrm{f}(\mathrm{x}, \mathrm{y})$, dan bidang $\mathrm{x}, \mathrm{y}$ menunjukkan informasi posisi spasial, yang disebut domain spasial. Operasi penyaringan berdasarkan lingkungan ruang xy disebut penyaringan domain spasial. Proses penyaringan adalah memindahkan filter titik demi titik pada fungsi citra $\mathrm{f}(\mathrm{x}, \mathrm{y})$ sehingga bagian tengah filter berhimpit dengan titik (x,y). Pada setiap titik (x, y), respons filter dihitung berdasarkan konten spesifik filter dan melalui hubungan yang telah ditentukan sebelumnya yang disebut template. Jika piksel di lingkungan dihitung sebagai operasi linier, itu juga disebut penyaringan domain spasial linier, jika tidak, itu disebut penyaringan domain spasial nonlinier. Gambar 3.3 menunjukkan proses penyaringan spasial dengan template $3 \times 3$ (juga dikenal sebagai filter, kernel, atau jendela).

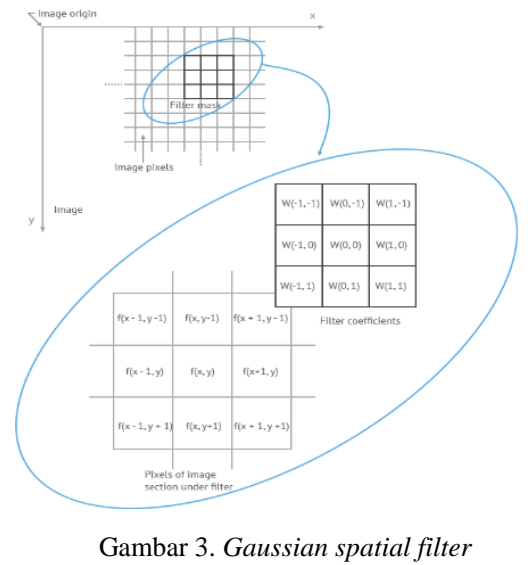

Sementara itu persamaan matematis gausian filter seperti dituliskan dalam persamaan 2 .

$$
G_{\sigma}(x, y)=\frac{1}{2 \pi \sigma^{2}} \exp ^{-\frac{x^{2}+y^{2}}{2 \sigma^{2}}}
$$

Gaussian filter pada penelitian ini digunakan untuk menghaluskan gradasi tepi citra. Kinerja gaussian filter ditunjukkan pada Gambar 4. Gambar 4(a) adalah citra dengan komponen warna $\mathrm{b}$ dari $\mathrm{L}^{*} \mathrm{a} * \mathrm{~b}$ dimana pada citra tersebut memperlihatkan noise pada ROI Rambu Lalulintas. Sementara komponen warna citra *a* gambar 4(b) adalah citra grayscale sebelum di filter. Adapun efek dari gaussian filter adalah noise yang ada menjadi sedikit pudar, gambar 4(c). 1
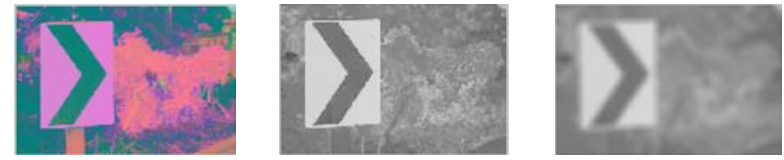

Gambar. 4 Kinerja dari gaussian filter, (a) citra L*a*b, (b) citra a dan (c) hasil filter gauss

\section{Segmentasi}

Proses partisi citra digital menjadi beberapa segmen didefinisikan sebagai segmentasi citra. Segmentasi bertujuan untuk membagi citra menjadi wilayah yang lebih representatif dan mudah dianalisis. Wilayah tersebut mungkin sesuai dengan permukaan individu, objek, atau bagian alami dari objek. Biasanya segmentasi gambar adalah proses yang digunakan untuk menemukan objek dan batas (misalnya, garis atau kurva) dalam gambar. Lebih lanjut, dapat didefinisikan sebagai proses pelabelan setiap piksel pada gambar, di mana semua piksel yang memiliki label yang sama memiliki karakteristik visual tertentu[15][16].

Pada penelitian ini proses segmentasi ROI menggunakan metode fuzzy c-means[17]. Struktur dari algoritma fuzzy c-means didasarkan pada konsep fuzzy $c$ partition. Tujuan dari fuzzy c-means adalah untuk menyelidiki derajat keanggotaan untuk setiap sampel data yang sesuai dengan setiap pusat cluster yang ditentukan (centroid). Hal ini dilakukan berdasarkan jarak antara centroid dan sampel data, di mana derajat keanggotaan mengambil nilai tinggi (mendekati 1) ketika sampel dekat dengan centroid. Ini mencerminkan kesamaan dari sampel data untuk pengelompokan.

Fuzzy cmean, algoritma pengelompokan fuzzy c-means (FCM) memungkinkan satu bagian data berada di lebih dari satu cluster berdasarkan fungsi keanggotaan[18]. FCM adalah teknik segmentasi yang populer digunakan dalam bidang segmentasi [19] [20][21]. Algoritna dasar dari metode fuzzy c-means, langkah awal adalah menentukan pusat cluster yang akan digunaan untuk menentukan lokasi rata-rata untuk tiap-tiap cluster. Pada kondisi awal ini, pusat cluster ini masih belum stabil. Tiap-tiap titik data memiliki derajat keanggotaan untuk tiap-tiap cluster. Derajat keanggotaan ini diperoleh dari proses fuzzy. Karean kondisi pusat cluster belum stabil maka dilakukan perbaikan pusat cluster dan derajat keanggotaan tiap-tiap titik data secara berulang, maka akan dapat dilihat bahwa pusat cluster akan bergerak menuju lokasi yang tepat. Perubahan secara kontinyu ini berpatokan pada minimisasi fungsi objektif yang didasari pada pengukuran jarak dari titik data yang diberikan ke pusat cluster yang terbobot oleh derajat keanggotaan titik data tersebut.

Dasar teori FCM adalah partisi terhadap data. Jika $X=$ $\left(x_{1}, x_{2}, \ldots, x_{n}\right)$ adalah kumpulan data numerik di $R^{\mathrm{d}}$ dan $\mathrm{c}$ menjadi bilangan bulat antara 1 dan $n$. Diberikan $X$, kita katakan bahwa c fuzzy subset $\left\{u_{k}: X \rightarrow[0,1]\right\}$ adalah partisi-c dari $X$ jika kondisi berikut terpenuhi[19]: 


$$
\begin{aligned}
& 0 \leq \mathrm{u}_{\mathrm{k}, \mathrm{i}} \leq 1 \quad \forall_{\mathrm{k}, \mathrm{i}} \\
& 0 \leq \sum_{k=1}^{c} u_{k, i}=1 \quad \forall_{\mathrm{k}, \mathrm{i}} \\
& 0<\sum_{i=1}^{n} u_{k, i}<n \quad \forall_{\mathrm{k}}
\end{aligned}
$$

Dimana $u_{k}, i=u_{k}\left(x_{j}\right), 1 \leq k \leq c$ dan $1 \leq i \leq n$. Misalkan $u_{k}$, memenuhi kondisi di atas yang diwakili oleh matriks $c$ $\times n, U=[u k, i]$. FCM bertujuan untuk menentukan pusat cluster $v_{k}(k=1 ; 2 ; . . ; c)$ dan matriks partisi fuzzy $U$ dengan meminimalkan fungsi tujuan $J$ didefinisikan sebagai berikut:

$$
J(U, V, X)=\sum_{K=1}^{C} \sum_{I=1}^{N} u_{k, i}^{m} d_{k, i}^{2}
$$

Dimana $d_{\mathrm{k}}$, adalah jarak Euclidean dari sampel $\mathrm{x}_{j}$ ke pusat cluster $v_{\mathrm{j}}$ didefinisikan sebagai:

$$
d_{k, i}=\sqrt{\sum_{j=1}^{d}\left(v_{k, j}-x_{i, j}\right)^{2}}
$$

Eksponen $m$ dalam persamaan (6) adalah tingkat fuzzynes yang terkait dengan matriks partisi $(m>1)$. Jika $m$ $=1$ maka soft clustering akan diubah menjadi hard case. Standar yang umum digunakan adalah $m=2$.

\section{Algoritm FCM[19]}

1. Pilih bilangan bulat $c$ dan nilai ambang batas. Misalkan $m$ to be equal to 2. Perbaiki dan inisialisasi matriks partisi fuzzy $U$ dengan nilai acak sehingga memenuhi kondisi (1), (2) dan (3).

2. Hitung nilai $\mathrm{v}_{\mathrm{j}}$ sebagai pusat fuzzy menggunakan

$$
v_{k}=\frac{\sum_{i=1}^{n}\left(u_{k, i}\right)^{m} x_{i}}{\sum_{i=1}^{n}\left(u_{k, i}\right)^{m}} \forall k 1, \ldots c
$$

3. Perbaiki partisi matrik fuzzy update $\mathrm{U}$ dengan

$$
u_{k, i}=\frac{1}{\sum_{k=1}^{c}\left(\frac{d_{k, i}}{d_{k, k}}\right)^{\frac{2}{m-1}}}
$$

Dimana $d_{k}$, dihitung menurut persamaan (7)

4. Hitung fungsi tujuan $J$ dengan menggunakan (5). Jika konvergen atau perbedaan antara dua nilai komputasi yang berdekatan dari fungsi tujuan $J$ kurang dari ambang yang diberikan maka berhenti. Jika tidak, lanjutkan ke langkah 2 .

Aplikasi FCM dalam penelitian ini menggunakan setting default yaitu: partisi matrik $=2$, jumlah iterasi $=100$, nilai perbaikan $=0,0005$.
Morphology, citra hasil segmentasi dengan FCM masih terdeteksi noise pada citra foreground, kondisi ini perlu dilakukan perbaikan citra. Pada tahap ini perbaikan dilakukan dengan menggunakan operasi morphology. Operasi Morphology, popular digunakan untuk mereduksi noise pasca operasi segmentasi[22], deteksi tepi ataupun konversi warna citra ke binary. Salah satu bagian dari metode morphology adalah erosion tepi. Erosion tepi, adalah proses yang populer diguanakan untuk menghapus noise hasil segmentasi yang di prediksi sebagai objek yang dikehendaki.

Dalam aplikasi praktis, erosion sering dipasangkan dengan dilatasi secara berurutan hasil dilatasi diikuti oleh hasil erosion, atau sebaliknya. Dalam kedua kasus tersebut, hasil penerapan dilatasi dan erosion secara iteratif adalah penghapusan detail gambar tertentu yang ukurannya lebih kecil daripada struktur elemen tanpa distorsi geometris dari fitur yang tidak proses. Model ini pertama kali dieksplorasi oleh Matheron (1975) dan Serra (1982). Kedua definisi [18] mereka untuk opening dan closing identik dengan yang diberikan di sini, namun formula mereka tampak berbeda karena mereka menggunakan simbol $\Theta$ (Minkowski) dari erosion yang memiliki arti penyusutan.

Definisi opening citra A dengan menggunakan strutur elemen B, dilambangkan dengan A o B, didefinisikan sebagai

$$
\mathrm{A} \text { o } \mathrm{B}=(\mathrm{A} \Theta \mathrm{B}) \oplus \mathrm{B}
$$

Definisi closing citra A dengan menggunakan strutur elemen B, dilambangkan dengan A • B, didefinisikan sebagai

$$
\mathrm{A} \bullet \mathrm{B}=(\mathrm{A} \oplus \mathrm{B}) \Theta \mathrm{B}
$$

Perlu dipahami bahwa symbol $\oplus$ dan $\Theta$, dapat merepresentasikan operasi dilatasi dan erosion untuk selain biner dan grayscale.

Opening dan closing dapat diartikan sebagai berikut: Pembukaan akan menghapus semua piksel di wilayah yang terlalu kecil untuk menampung probe. Urutan yang berlawanan, closing, akan mengisi area lubang dan cekungan lebih kecil dari pada probe. Filter semacam itu dapat digunakan untuk menekan fitur objek atau membedakan objek berdasarkan bentuk atau distribusi ukurannya

Pada penelitian ini operasi Morphology yang diterapkan adalah operasi opening, Pada Gambar 5(b) ditunjukkan citra biner sebagai ROI dari hasil segmentasi yang tidak sempurna pada saat melokalisir ojek yang diinginkan. Hal ini ditunjukkan terdapat area hitam di dalam ROI dan terdapat noise. Sementara itu Gambar 5(c) adalah citra hasil proses erosion sudah tidak terdapat noise lagi.
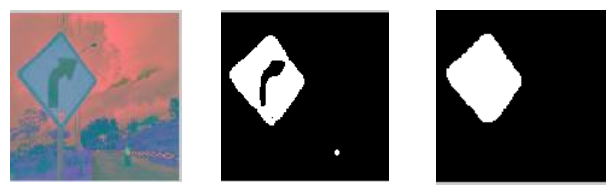

Gambar 5. Kinerja Erosion (a) citra asal, (b) hasil FCM dan (c) pasca erosion 
Hole Filling, sebagaimana telah diperlihatkan pada Gambar 5 sebagai hasil dari tahapan proses morphology diperoleh ROI citra binary, namun demikian masih didapati hole. Oleh karena itu diperlukan proses filling pada lubang gambar 6(b) tersebut agar diperoleh area sempurna sebagaimana ditunjukkan pada Gambar 6(c).
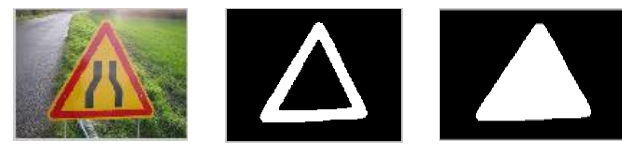

Gambar 6. Kinerja hole filling, (a) citra asal, (b) citra binar dan (c) pasca hole filling

Mask Thresholder, adalah kebaruan teknik/model kernel yang ditawarkan pada penelitian. Mask thresholder yang ditawarkan ini mempunyai dimensi citra yang sama dengan citra semula (asli) namun hanya mempunyai nilai piksel $[0,1]$. Hal ini berbeda dengan jenis kernel pada umumnya untuk convolusion pada proses deteksi tepi atau porses perbaikan kekontrasan warna citra yang menggunakan dimensi jauh lebih kecil dari citra semula dan nilai 0 serta pusat kernel. Mask thresholder pada penelitian ini adalah citra hasil akhir dari proses segmentasi seperti dicontohkan pada Gambar 6(c). Keunggulan kernel mask thresholder, ROI mempunyai posisi yang sama dengan objek yang akan disegmentasi dari sebuah citra. Dengan model kernel seperti ini diharapkan pada proses segmentasi objek dapat diperoleh dengan presisi tinggi.

\section{Konvolusi dengan Mask Thresholder}

Konvolusi, adalah teknik untuk memperoleh citra baru dengan teknik operasi perkalian dari dua buah data matrik. Pada penelitian ini konvolusi dilakukan untuk mendapat ROI citra warna sebagai hasil segmentasi. Metode yang digunakan adalah dengan menerapkan citra hasil segmentasi yang telah dilakukan proses morphology sebagai masker. Proses konvolusi dilakukan dengan perkalian tiap komponen citra warna semula (RGB) dengan citra masker dalam format binary $f(x, y)$ pada persamaan (10) dari hasil segmentasi FCM (gambar 6 (c) ). Matrik $r($ ), $g($ ), dan $b()$ masing masing mempunyai nilai piksel dari citra asal yaitu 0 sampai dengan 255, $\left(\mathrm{x}_{\mathrm{i}}, \mathrm{y}_{\mathrm{j}}\right)=0 \ldots 255$. Sementara $f\left(x_{i}, y_{j}\right)$ adalah citra binary bernilai [0 1]

$$
\begin{aligned}
& \operatorname{Rf}\left(x_{i}, y_{j}\right)=r\left(x_{i}, y_{j}\right) * f\left(x_{i}, y_{j}\right) \\
& \operatorname{Gf}\left(x_{i}, y_{j}\right)=g\left(x_{i}, y_{j}\right) * f\left(x_{i}, y_{j}\right) \\
& \operatorname{Bf}\left(x_{i}, y_{j}\right)=b\left(x_{i}, y_{j}\right) * f\left(x_{i}, y_{j}\right)
\end{aligned}
$$

\section{E. Konstruksi Komponen Citra}

Konstruksi komponen citra adalah proses menyusun komponen $R f, \quad G f$ dan $B f$ hasil konvolusi dengan mengaplikasikan persamaan (10) menjadi satu unit warna citra $R G B$. Proses ini menggabungkan komponen $R f, G f$ dan $B f$ menjadi citra hasil segmentasi (Gambar 7 (c)). Kinerja konstruksi citra ditunjukkan oleh Gambar 7.

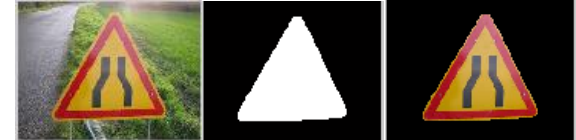

Gambar 7. Kontruksi komponen Rf, Gf, Bf dan hasil segmentasi, (a) citra input, (b) citra binar dan (c) hasil konstruksi

Setelah dilakukan proses konstruksi citra dalam bentuk perkalian citra semula dalam ruang warna RGB dan citra hasil segmentasi dalan ruang warna binary maka di peroleh tanda rambu jalan dalam dalam ruang warna RGB, seperti diperlihatkan pada Gambar 7 (c).

\section{HASIL DAN PEMBAHASAN}

\section{A. Evaluasi Metode}

Evaluasi terhadap metode yang diusulkan ditinjau berdasarkan segmentation accuracy (Sc). Sc digunakan untuk mengukur kemiripan dua citra A dan B. Citra A dalam penelitian ini adalah citra ground truth. Sementara citra B adalah citra yang dihasilkan oleh metode yang diusulkan.

Pengukuran kemiripan pada penelitian ini menggunakan metode jaccard seperti dituliskan pada persamaan (11)

$$
S c=\frac{|A \cap B|}{|A \cup B|}=\frac{|A \cap B|}{|A|+|B|-|A \cap B|}
$$

Pada persamaan 11 ditetapkan nilai $(0<=\mathrm{Sc}<=1)$ jika Sc bernilai 0 diartikan sebagai citra A dan B tidak memiliki kemiripan. Sementara jika Sc bernilai satu dapat diartikan memiliki kemiripan (akurasi) 100\%. Oleh karena itu pada penelitian ini tingkat akurasi segmentasi diukur menggunakan metode jaccard.

\section{B. Kinerja Metode}

Pengujian metode yang diusulkan telah dilakukan pada citra rambu lalulintas yang dikumpulkan sejumlah 72 citra dari sumber di internet. Format citra yang di pergunakan dalam penelitian ini adalah JPEG. Sementara itu ukuran citra adalah $200 \times 200$ hasil dari resize citra asal. Dataset citra dikelompokkan berdasarkan kompleksitas latar belakang citra. Pada penelitian ini ditentukan sejumlah tiga kelompok yaitu: 1) citra dengan latar belakang homogen, 2) citra dengan kompleksitas latar belakang rendah dan 3) citra latar belakang dengan kompleksitas tinggi.

Hasil pengujian pada citra kelompok pertama yaitu citra dengan latar belakang homogen menunjukkan motode yang diusulkan berhasil dengan sempurna mengenal objek yang diujikan. Pada kelompok ini telah diujikan sejumlah lima citra. Lima citra tersebut semua dapat disegmentasi dengan sempurna. Berdasarkan pengukuran dengan jaccard didapat tingkat akurasi rata-rata 96,95\%. Hasil segmentasi seperti ditunjukkan pada Tabel 1. 
TABEL I

SEGMENTASI DENGAN LATAR BELAKANG HOMOGEN

\begin{tabular}{|l|l|l|l|}
\hline No & Citra input & $\begin{array}{c}\text { Sc } \\
\text { (\%) }\end{array}$ \\
\hline Segmentasi & & \\
\hline & & & \\
\hline
\end{tabular}

Hasil pengujian pada citra kelompok dua, citra dengan latar belakang kompleksitas rendah. Terhadap lima citra ini menunjukkan bahwa motode yang diusulkan berhasil dengan baik mengenal objek yang diujikan. Lima citra uji mampu disegmentasi dengan seluruhnya. Namun demikian seperti pada pengujian nomor 3 terdapat kurang sempurna dalam segmentasi karena masih terdapat background yang dikenali sebagai ROI. Hasil yang diperoleh untuk pengujian terhadap kompleksitas latar belakang rendah didapat tingkat akurasi rata-rata $98,10 \%$ seperti ditunjukkan pada Tabel 2.

TABEL III

SEGMENTASI DENGAN KOMPLEKSITAS LATAR BELAKANG RENDAH

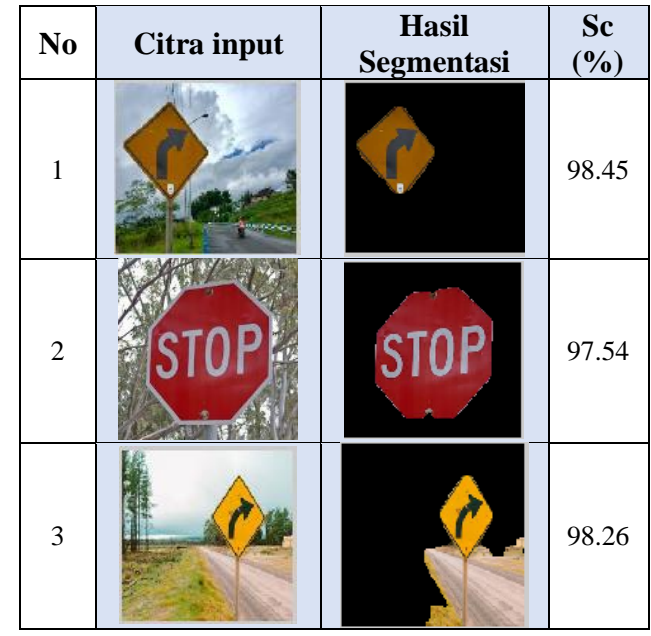

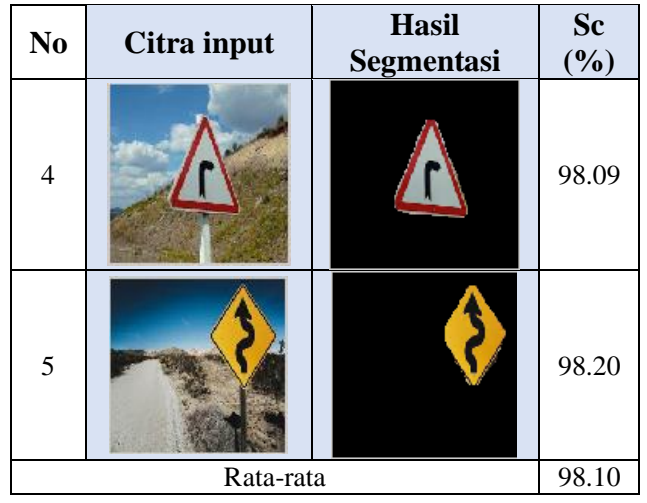

Hasil pengujian citra dengan latar belakang dengan kompleksitas tinggi menunjukkan motode yang diusulkan berhasil mengenal tanda rambu jalan yang diujikan. Pada kelompok ini telah diujikan sejumlah tujuh citra. Hasil yang diperoleh untuk pengujian terhadap kompleksitas latar belakang yang tinggi adalah seperti di perlihatkan oleh Tabel 3. Pada kelompok ini metode mampu mengenali ROI dengan tepat. Sementara itu kinerja metode yang dtawarkan pada kelompok ini didapat tingkat akurasi rata-rata adalah $98.15 \%$.

TABEL IIIII

SEGMENTASI DENGAN KOMPLEKSITAS LATAR BELAKANG TINGGI

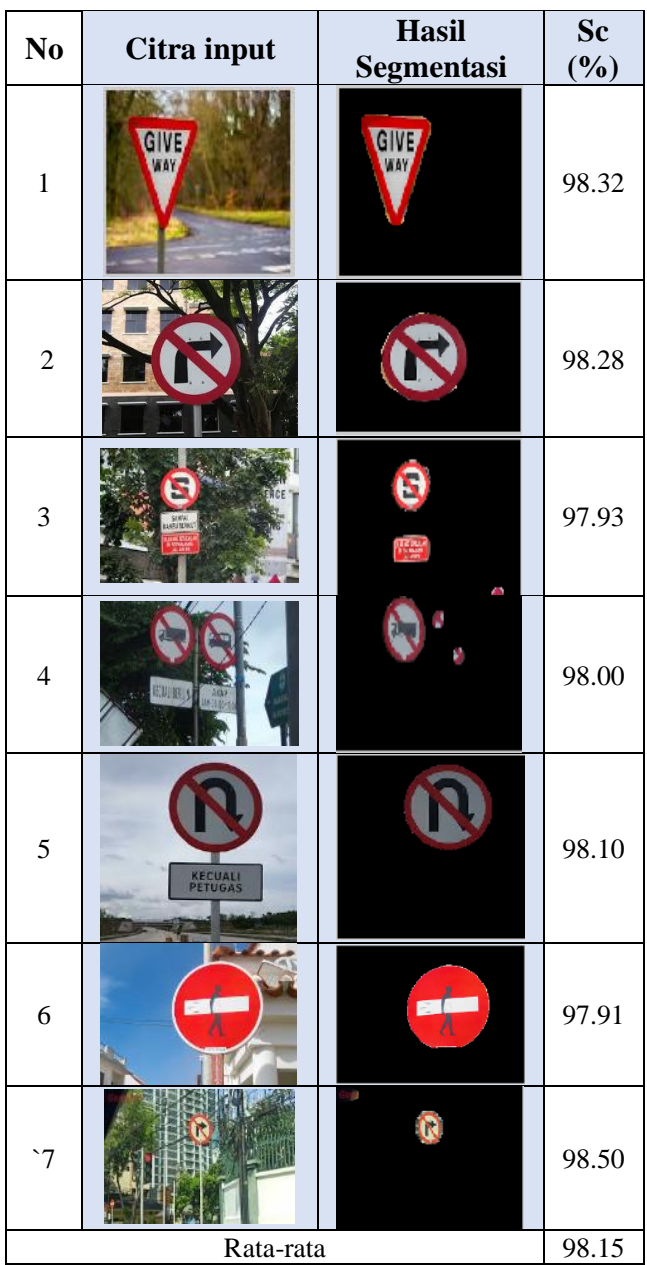


Berdasarkan pengujian terhadap tiga kelompok citra dengan hasil tertera pada Tabel 1, Tabel 2 dan Tabel 3 menunjukkan kinerja model yang ditawarkan mampu menampilkan citra segmentasi dalam ruang warna dengan akurasi tinggi yaitu rerata secara keseluruhan 97,73\%.

Hasil pengujian pada Tabel 3 diperlihatkan ada tiga tanda rambu jalan untuk kategori himbauan dalam bentuk teks dengan tulisan berwarna hitam dengan background putih yang gagal disegmentasi, yaitu dipercobaan 3, 4 dan 5. Teks hitam yang berlatar belakang putih (RGB) saat di konversi ke ruang warna $\mathrm{L}^{*} \mathrm{a} * \mathrm{~b}$ tidak mengalami kesalahan. Namun saat komponen tersebut diekstraksi untuk komponen warna $* a *$ ternyata di dapati bahwa komponen warna $* a *$ terlihat gelap dan tidak menampakan teks (foreground) yang ada. Untuk mendapat fakta yang benar terkait temuan ini, maka telah dilakukan pengujian dengan 2 tindakan. Pertama merubah rambu tersebut dengan background berwarna kuning dengan teks tetap berwarna hitam. Hasil yang diperoleh menunjukkan bahwa metode mampu mensegmentasi dengan sempurna. Kedua, dengan merubah teks menjadi berwarna merah dengan background tetap putih. Hasil yang diperoleh menunjukkan bahwa metode mampu mensegmentasi dengan sempurna. Berdasarkan fakta ini, penggunaan citra warna $L * a * b$ tidak mendukung untuk segmentasi rambu jalan dalam bentuk teks yang tertulis dengan warna hitam dengan background putih.

\section{KESIMPULAN}

Metode Fuzzy c-means dengan mask thresholder pada proses segmentasi format citra $\mathrm{L}^{*} \mathrm{a} * \mathrm{~b}$ dengan latar belakang homogen mampu melakukan segmentasi dengan sempurna dengan akurasi rata-rata $96.95 \%$. Sementara untuk citra dengan latar belakang kompleksitas rendah metode yang diusulkan dapat mengenali ROI dengan akurasi $98.10 \%$ namun ada sedikit noise dari hasil segemtasi. Demikian juga pada citra dengan kompleksitas latar belakang tinggi metode yang diusulkan mampu mengenali simbol rambu lalulintas dengan benar dan akurasi kinerja sebesar 98.15\%. Secara keseluruhan metode yang ditawarkan mampa menghasilkan sitra segmentasi dalam ruang warna dan mempunyai rerata akurasi tinggi yaitu sebesar 97,73\%.

\section{REFERENSI}

[1] Z. Afrose and M. Al-Amin Bhuiyan, "Road Sign Segmentation and Recognition under Bad Illumination Condition using Modified Fuzzy C-means Clustering," Int. J. Comput. Appl., vol. 50, no. 8, pp. 1-6, 2012, doi: 10.5120/7788-0888.

[2] R. E. F. Rizarta and D. Avianto, "Pengenalan Citra Rambu Lalu Lintas Menggunakan Ekstraksi Fitur Momenwarna Dan KNearest Neighbor," Comput. J. Comput. Sci. Inf. Syst., vol. 3, no. 1, p. 39, 2019, doi: 10.24912/computatio.v3i1.4272.

[3] K. Anwar and S. Setyowibowo, "Segmentasi Kerusakan Daun Padi pada Citra Digital," vol. 7, no. 1, pp. 39-43, 2021.

[4] J. Balado, M. Soilán, L. Díaz-Vilariño, and P. van Oosterom,
"Segmentation of Traffic Signs From Poles With Mathematical Morphology Applied To Point Clouds," ISPRS Ann. Photogramm. Remote Sens. Spat. Inf. Sci., vol. V-2-2021, pp. 145-151, 2021, doi: 10.5194/isprs-annals-v-2-2021-145-2021.

[5] S. Dutta and B. B. Chaudhuri, "Homogenous Region based Color Image Segmentation,” vol. II, 2009.

[6] N. Ikonomakis, K. N. Plataniotis, and A. N. Venetsanopoulos, "Color Image Segmentation for Multimedia Applications," pp. $5-20,2000$.

[7] O. R. Sitanggang, H. Fitriyah, and F. Utaminingrum, "Sistem Deteksi dan Pengenalan Jenis Rambu Lalu Lintas Menggunakan Metode Shape Detection Pada Raspberry Pi," J. Pengemb. Teknol. Inf. dan Ilmu Komput. Univ. Brawijaya, vol. 2, no. 12, 2018.

[8] A. Septiarini, H. Hamdani, H. R. Hatta, and K. Anwar, "Automatic image segmentation of oil palm fruits by applying the contour-based approach," Sci. Hortic. (Amsterdam)., vol. 261, no. October 2019, p. 108939, 2020, doi: 10.1016/j.scienta.2019.108939

[9] X. Ni, C. Li, H. Jiang, and F. Takeda, "Deep learning image segmentation and extraction of blueberry fruit traits associated with harvestability and yield," Hortic. Res., vol. 7, no. 1, 2020, doi: 10.1038/s41438-020-0323-3.

[10] H. Kang, "Fruit Detection and Segmentation for Apple," 2019, doi: 10.3390/s19204599.

[11] Y. Abbaspour-gilandeh, "A Video Image Segmentation System for the Fruit-trees in Multi-stage Outdoors Orchard under Natural Conditions," 2018, doi: 10.15832/ankutbd.434137.

[12] S. Lailee, S. Abdullah, H. Aini, and N. Jamil, "Segmentation of Natural Images Using an Improved Thresholding-based Technique," vol. 41, no. Iris, pp. 938-944, 2012, doi: 10.1016/j.proeng.2012.07.266.

[13] Z. Wang and S. Zhang, "Segmentation of Corn Leaf Disease Based on Fully Convolution Neural Network," vol. 1, no. 1, pp. 9-18, doi: 10.25236/AJCIS.010002.

[14] G. Sun, X. Jia, and T. Geng, "Plant Diseases Recognition Based on Image Processing Technology," vol. 2018, pp. 1-8, 2018.

[15] D. Khattab, H. M. Ebied, A. S. Hussein, and M. F. Tolba, "Color image segmentation based on different color space models using automatic GrabCut," Sci. World J., vol. 2014, 2014, doi: $10.1155 / 2014 / 126025$.

[16] J. Delon, A. Desolneux, J. Lisani, and A. B. Petro, "A Nonparametric Approach for Histogram Segmentation," no. February 2007, 2014, doi: 10.1109/TIP.2006.884951.

[17] N. Singh and S. Veenadhari, "Segmentation of fuzzy enhanced mammogram mass images by using K-mean clustering and region growing," Int. J. Adv. Comput. Sci. Appl., vol. 11, no. 5, pp. 348-352, 2020, doi: 10.14569/IJACSA.2020.0110546.

[18] M. Nazari, "Improve Semi-Supervised Fuzzy C-means Clustering Based On Feature Improve Semi-Supervised Fuzzy C-means Clustering Based On Feature Weighting," no. January 2013, 2016.

[19] A. Hamad, S. Aminifar, and M. Daneshwar, "An interval type2 FCM for color image segmentation," vol. 10, no. 46, 2020.

[20] M. Akbar et al., "GPU ACCELERATED FUZZY C-MEANS ( FCM ) COLOR IMAGE,” vol. 3839, pp. 165-174.

[21] S. Arumugadevi, "Color Image Segmentation Using Feedforward Neural Networks with FCM," vol. 13, no. October, pp. 491-500, 2016, doi: 10.1007/s11633-016-0975-5.

[22] A. O. Chime, R. O. Aiwansoba, M. E. Osawaru, and M. C. Ogwu, "Morphological Evaluation of Tomato ( Solanum lycopersicum Linn .) Cultivars," vol. 21, no. 2, pp. 97-106, 2017, doi: $10.7454 / \mathrm{mss} . v 21 \mathrm{i} 2.7421$. 